\title{
Insight
}

\section{Can We Be Both Resilient and Well, and What Choices Do People Have? Incorporating Agency into the Resilience Debate from a Fisheries Perspective.}

\author{
Sarah Coulthard $^{1}$
}

\begin{abstract}
In the midst of a global fisheries crisis, there has been great interest in the fostering of adaptation and resilience in fisheries, as a means to reduce vulnerability and improve the capacity of fishing society to adapt to change. However, enhanced resilience does not automatically result in improved well-being of people, and adaptation strategies are riddled with difficult choices, or trade-offs, that people must negotiate. This paper uses the context of fisheries to explore some apparent tensions between adapting to change on the one hand, and the pursuit of well-being on the other, and illustrates that trade-offs can operate at different levels of scale. It argues that policies that seek to support fisheries resilience need to be built on a better understanding of the wide range of consequences that adaptation has on fisher well-being, the agency people exert in negotiating their adaptation strategies, and how this feeds back into the resilience of fisheries as a social-ecological system. The paper draws from theories on agency and adaptive preferences to illustrate how agency might be better incorporated into the resilience debate.
\end{abstract}

Key Words: adaptation; agency; fisheries; resilience

\section{INTRODUCTION}

Globally, fisheries are in crisis (Jackson et al. 2001, Pauly et al. 2002, Worm et al. 2009). Already threatened by overfishing, habitat loss, and inadequate systems of governance (Beddington et al. 2007, Garcia and Charles 2008), fisheries are also in a weak position to cope with a new set of challenges arising from the impacts of climate change (Allison et al. 2009). The implications for human well-being are severe; the fisheries sector provides an estimated 120 million livelihoods globally, with $97 \%$ of fishers living in developing countries (World Bank/FAO/WorldFish Center 2010); many more people depend upon protein rich fish as a basis for their food security (Allison and Ellis 2001). Given the growing vulnerability that fishers around the world face, there has been much interest in the fostering of adaptation among fishing peoples (FAO 2007, Daw et al. 2009), i.e., the capacity of people to adjust their behavior to cope with change and disturbance (Folke et al. 2010), and the enhancement of resilience in fisheries (Allison et al. 2007, WorldFish 2010).

Adaptability is an important contributor to the overall resilience of an integrated social-ecological system (Berkes and Folke 1998, Folke et al. 2010), which, in a fisheries context, can constitute the whole of the marine resource and environment, and the people dependent upon it. Resilience is understood here to be the capacity of the (fisheries) system, as a whole, to respond to disturbance and shocks while maintaining essential functions (Walker et al. 2004, Folke et al. 2005, Folke 2006). Resilience theorists describe system responses in terms of absorption of change, reorganization, self-learning, and innovation (Walker et al. 2004, Folke 2006, Armitage and Plummer 2010). A desirable outcome of resilience, which appeals to its application in fisheries, is the retention of essential functions of the system. This could be interpreted as the long-term sustaining of jobs, valued identities, and cultures in fishing societies, alongside resilient marine resources and sustained ecological health. Furthermore, as the WorldFish Centre, which promotes resilient small-scale fisheries as one of its core activities, states: "Resilient fisheries are less vulnerable to the adverse effects of changing circumstances and can adapt more quickly" (www.worldfish.org/).

Greater resilience of social-ecological systems that can respond to shocks and retain essential functioning is clearly an appealing goal, which drives attempts to establish the determinants of resilience and how it might be supported at local and national levels (Berkes and Folke 1998, Adger et al. 2005, Brooks et al. 2005). However, the pursuit of resilience at a systems level needs to be coupled with greater consideration of the consequences of adaptation, a prerequisite of resilience (Folke et al. 2010), for human well-being at the local level. This is for two reasons; first a moral concern that adaptation strategies, although reducing risk on the one hand, may also incur forms of harm and ill-being that need to be accounted for in policies that promote adaptation as a means of risk reduction. The second, related, reason is that the pursuit of well-being, and what people perceive as a desirable way of life, is a major determinant of what people do and the decisions they make, in both their daily lives and longer term life strategizing (Gough and McGregor 2007, McGregor 2009). As such, the pursuit of well-being has the power to facilitate, but also restrict, adaptation at the local level, and can shape the overall resilience of the social-ecological system. 
Although the Millennium Ecosystem Assessment clearly acknowledges the threat of ecosystem service loss to human well-being (MEA 2005a), and advocates adaptation as a means of mitigating the risks associated (MEA 2005b), far less is understood about the impacts of adaptation itself on people. Scenarios research within the MEA on adaptive mosaics illustrate some of the well-being benefits from adaptive learning within communities, with some interesting examples of how people have innovated to overcome environmental risk such as drought (MEA 2005c). However, some fundamental questions remain about the social implications of adaptation; for example, how the gains and losses of adaptation, and being part of a resilient system, are distributed within society (Adger et al. 2007), and the degree of choice people have in determining the ways in which they adapt and contribute to resilience. These questions are more fully addressed in the climate change literature, especially in the context of climate injustice (see Paavola and Adger 2005, Smit and Wandel 2006), but have received far less attention in the realm of marine resource management, despite the role that local decision making plays in facilitating resilient and sustainable fisheries. As Walker et al. (2004:5) state, adaptability is "the capacity of actors in a system to influence resilience" and as such it draws attention to people and decision making at the local level.

Sometimes resilience and well-being are considered to be the same thing, recognizing the benefits that actors within a system may receive by being less vulnerable to shocks and having greater coping capacity to live with environmental change (see Marschke and Berkes 2006 who use the concept of well-being as a surrogate for household-level resilience in Cambodia). Greater resilience at a systems level however, does not straightforwardly, or automatically, equate greater well-being of people operating within it. Adaptation choices can include compromises and trade-offs between the pursuit of well-being on the one hand and, on the other, the necessity for adaptation strategies that reduce vulnerability and risk. Trade-offs can occur at different scales; decision-making at the individual level, the main focus of the agency angle taken here; at a societal level between different people who have differing degrees of risk exposure and varied coping capacities; and between individuals and the social-ecological system. Vulnerability, defined here as susceptibility to harm (Adger 2006, 2010), is often assumed to be the antonym of resilience, which has perhaps stimulated further assumptions on how resilience and well-being relate. But, as Gallopín (2006) recognizes, this relationship does not imply symmetry, but is complex, often context specific, and sometimes paradoxical (Adger 2006).

In the context of climate change, Adger (2006) describes a vulnerability-resilience paradox that asserts that high vulnerability can sometimes accompany greater resilience. He draws from the observation that although some countries can be considered as vulnerable to climate change, they can be equally credited with high levels of resilience through local knowledge and experience of coping with climatic variation (for example, in the Arctic; see Berkes and Jolly 2001). This type of paradox is recognized across different disciplines too. For example, in developmental science, studies on how children cope with trauma emphasize the sensitivities around shifting the focus of analysis from vulnerability and risk to resilience and the delicate balance between acknowledging children's risk on the one hand, and resourcefulness and adaptability on the other (see Panter-Brick 2002). Similarly, Lister (2004:136) comments that many studies on poverty have pointed out the danger of "painting too rosy a picture of resourcefulness," that ignores the hardships incurred.

A challenge then for a resilient fisheries agenda is how to balance the promotion of resilience, and enhanced capacity to adapt to change and crisis, with equal recognition of the vulnerability fishers face and the unacceptable poverty that is often endured (Allison and Horemans 2006, Béné 2009). The central tenet of this paper is that the resilience discourse needs to more explicitly engage with the concepts of well-being to assess the implications of adaptation on well-being outcomes, and agency, to understand the choices people have in determining their adaptation strategies. As is reflected in the article title, questions remain around whether people can adapt to change while maintaining well-being, to contribute to system-level resilience and, if not, what choices do people have and make? The concept of agency can form a useful linking concept between resilience and well-being, which emphasizes this process of negotiation.

McLaughlin and Dietz (2008) also stress the importance of integrating agency into debates on environmental vulnerability and offer a three-pronged rationale: (i) human actors are never just passive in the face of environmental threat, and as such their actions should be treated as independent variables that can influence the nature of the threat, not just as responses to it; (ii) people have their own priorities, which may differ from those of researchers and development agencies. Therefore understanding how they frame their own well-being is crucial to mitigating their vulnerability; (iii) the framings by which people live, and act, are central to legitimizing choices that ultimately determine the vulnerabilities experienced. In climate change discourse, Smit and Wandel (2006) point out that a great deal of adaptation research is top-down, led by researchers or scenario/modeling, and suggest that adaptation measures may be more effective if they are attentive to adaptation in practice, i.e., the way that communities experience adaptation and the process of decision making. Interestingly, the same call for attention to process is made by resilience theorists in developmental studies:

Research will gain very little if it confines itself to a mechanistic search for protective factors as those sets of variables that will predict resiliency with fair consistency ... Instead, it must appraise the 
developmental and contextual processes by which some individuals manage to negotiate adversity (why and how they maintain self-esteem and selfefficacy; how they managed to have effective social networks). It is wrong to assume that vulnerability or protection lies in the variable (e.g., social support) per se, rather than in the active role taken by individuals under adversity: Resilience is a reflection of an individual's agency. (Rutter 1990, as cited in Panter-Brick 2002:163).

Resilience as a "reflection of an individual's agency" is an interesting idea, and perhaps stresses the connection between actor-orientated and systems thinking. In their discussion on social limits to adaptation' Adger et al. (2008) further emphasize the social nature of agency. The authors question the ways in which society itself influences, and limits, adaptive capacities, focusing on the roles of ethics, i.e., what is valued by a society, knowledge, perceived risk, and culture. This centrality of values (see also O'Brien 2009) helps to define more clearly what socially acceptable levels of risk are, and to what degree adaptation is perceived as necessary and plausible. It places social choice and the negotiation of adaptive strategies at the heart of the analysis.

This paper seeks to add to these debates by exploring the relationship between resilience at a systems level, well-being, and agency exerted by individuals, operating within social and cultural structures. It draws from a fisheries context, using both real-life and theoretical cases of fisher decision making. The paper first discusses the role of the agency in helping illuminate decision making processes around adaptation, and an agency framework (Lister 2004) is applied to illustrate different expressions of agency in a fisheries context. The social construction of agency is also discussed, drawing on long-standing debates in the social sciences on the interaction between social structures and individual agency. The discussion then moves to consider implications of adaptation for people's well-being, and in particular, the problem of dealing with adaptive preferences, the capacity for people to adapt and live with reduced well-being as a consequence. An illustrative example from fisheries then draws together these two debates, i.e., agency and well-being, and highlights some of the choices and trade-offs that fishers and their families face in their negotiation of resilience processes.

\section{THE ROLE OF AGENCY IN RESILIENT FISHERIES}

The concept of agency is typically used to characterize individuals as "autonomous, purposive and creative actors, capable of a degree of choice" (Lister 2004:125). An agentbased philosophy recognizes people as being active agents who can, to some degree, negotiate their own lives, including their adaptive strategies, in the face of adverse circumstances. In much of the debate on resilience and social-ecological systems, the agency of people is often veiled (Bohle et al.
2009), focusing instead on the ability of the system to recover from shocks rather than the choices exercised by individuals within the system (Folke 2006, Young et al. 2006), which can influence the ways in which resilience is shaped. Nelson et al. (2007:399) comment that a focus on the individual and decision making is more the domain of the adaptation literature, which has evolved from a development discourse, in contrast with resilience theory and its background in ecology and systems thinking, but they also acknowledge the challenge in reconciling actor- and system-oriented approaches. In the same vein, Folke (2006) comments on the growing efforts to integrate the social dimension within resilience research, to help bridge social-ecological systems thinking (see also Adger 2000, Gunderson and Holling 2002), and a centralization of agency within resilience debates can contribute to these advances.

In her research on poverty and citizenship, Ruth Lister (2003, 2004) distinguishes between four dimensions of agency (Fig 1): 'everyday agency,' the daily decision making around how to make ends meet; 'strategic agency,' which involves decision making around longer term strategies; 'personal agency,' which reflects individual's own choices; and 'political and citizenship agency,' which connects to the capacity of people to affect wider change. Lister (2004:129) stresses that each dimension of agency is interrelated; for example, to act politically, one first requires a sense of personal agency or a "belief that one can act", while acting as a citizen further strengthens that sense of personal agency. Fig. 1 illustrates how Lister's agency model might be applied to understand fisher behavior and adaptation strategies. Also included is an example of a fisheries-based research article that illustrates each form of agency as described in the model.

Lister's connection of personal agency with political agency is significant, and relates to debates from Giddens (1984) and Long and van der Ploeg (1994) about the meaning of agency and how it is socially embedded. These scholars argue that agency cannot simply refer to intentions, or capacity to make decisions, but must represent the capability of a person to act and make a difference to a pre-existing state of affairs or events. Such a definition of agency, they argue, necessarily involves social relations and can in fact only function through them. As Long and Long (1992:23) describe:

Agency therefore requires organizing capacities; it is not simply a result of possessing certain cognitive abilities ... agency (and power) depend crucially upon the emergence of a network of actors who become partially, though hardly ever completely, enrolled in the projects and practices of some other person or persons. Effective agency then requires the strategic generation/manipulation of a network of social relations. 
Fig. 1. Forms of agency exercised by people in poverty, applied to a fisheries context. Adapted from Lister (2004:130). Published with permission from Polity press.

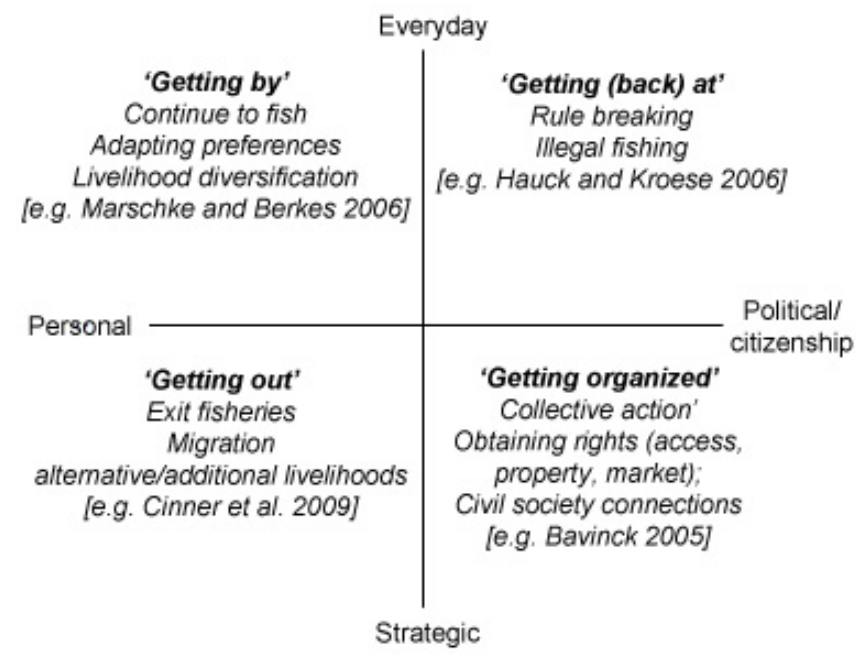

A social concept of agency compels us to consider collective forms of action that are dependent on social bonds and relationships with others (Ostrom et al. 1999, Adger 2003, Osbahr et al. 2010). In fisheries, this is pertinent because adaptation strategies are frequently expressed through political or 'getting organized' forms of agency that are often strengthened through partnership with civil society and fisher movements (Jentoft and McCay 2003, Sunde and Isaacs 2008). For example, illegal fishing/rule breaking ('getting back at' agency) may, through relationships with others, evolve into 'getting organized agency' expressed in collective action and self-organization (Bavinck and Hoefnagel 2005), or sustained protest and campaigning for fishing rights (Sunde 2008). Social network analysis is one analytical approach which seeks to identify the different types of relationships that are important in fostering political agency, and the ways in which this can facilitate or hinder societal adaptation, learning, and natural resource governance (see Bodin and Crona 2009, Crona and Hubacek 2010).

The relevance of relationships with others in exerting agency relates to an important and long-standing debate in sociology around structures, and the degree to which social structures, i.e., factors such as class, religion, norms, rules, institutions, culture, gender etc., affect the capacity of individuals to act independently and to have agency, i.e., to make free choices, (Abercrombie et al. 1984). Long and van der Ploeg (1994) give a useful overview of the two models: structural and actororientated. Structural perspectives place emphasis on external forces, often the role of the state, market, and institutions, that direct people's behaviors and reduce individual autonomy.
Within fisheries, structures of fisheries legislation, market dynamics, and institutions of community, family, and norms around gender are especially influential in shaping adaptation decisions of individuals (Ram 1991, Bavinck 2001, Jentoft 2004, Bennett 2005, Marchal et al. 2007). Counter to this is what Long and van der Ploeg (1994) refer to as the 'actororientated paradigm,' which places emphasis on the capacity for social actors to mediate their own decisions, and hence actions, according to their own consciousness. Theorists over the years have attempted to find a position of balance between these two perspectives arguing that both structure and agency can be mutually influential in shaping what people can do (Bourdieu 1990, Giddens 1976, 1984). The theory of structuration proposed by Anthony Giddens (1984) reconciles the agency/structure debate by proposing that all humans express agency in the context of pre-existing social structures governed by a set of norms in which they live, but that people are also active agents capable of modifying and changing those structures. Drawing from Giddens (1976), Camfield and McGregor (2005:19) describe how structures can both enable and constrain behaviors in a range of different ways:

These include restricting options physically (e.g. poor infrastructure limiting access to markets or health and education facilities); socially (e.g. community rules restricting the access of some members of the community to natural resources); and by limiting the range of what can be thought ( $e$. g. cultural limitations on the prospect of women challenging the decisions of males).

In unpacking the decision making processes in adaptation in fisheries, these structural contexts are crucial and illuminate the ways in which relationships with others can facilitate or restrict peoples' capacity to pursue well-being or be part of a resilient system. Gidden's theory of structuration seems also to relate to current thinking on adaptive governance (Dietz et al. 2003, Folke et al. 2005, Armitage et al. 2008), in which feedback processes and learning enable individuals to adapt and modify their structures of governance.

Another challenge to consider is that different combinations of agency may be exerted over time, and in different circumstances, pending on both opportunity and perceived necessity for adaptation. Coulthard (2009) suggests, in the language of resilience theory, that certain thresholds, or tipping points, may be identifiable at which point a fisher's livelihood can be transformed into an entirely different state, for example, the decision to sell up and permanently leave the fishery (Lister's concept of 'getting out'). Ellis (2000:56) however argues that "Choice, or lack of it, does not obey some sort of definable break point between two mutually exclusive states ... households and individuals can also move back and forth between choice and necessity, seasonally and across years." In fisheries, the unpredictability of the catch, and the 
usual oscillating productivity of the fishery, mean that perceived necessities to adapt will wax and wane over any given period (Coulthard 2009). As such, fishers are regularly documented as choosing short-term, and often inadequate, coping strategies as a means of 'getting by' during hard times, amidst hope of future revival in the fishery or the promise of 'the big catch' (see Finlayson and McCay 1998, Binkley 2000, Coulthard 2008).

\section{THE PROBLEM OF ADAPTIVE PREFERENCES}

The idea of fishers 'putting up with' and 'getting by' in times of hardship raises questions about the ways in which adapting to circumstances affects fisher well-being. As was argued in the introduction, increased resilience, adaptive capacity to cope with stresses and shocks, and reduced vulnerability may lead to different well-being outcomes, not all of them complementary (see Davies 1996). In the field of development ethics, the recognition that people can adapt to poverty and deprivation by "learning to suppress their wants, hopes and aspirations" has received growing importance (Sen 1999, Nussbaum 2001, Clark 2007:25). Qizilbash (2006) refers to this as 'the adaptation problem': if people's desires and attitudes are malleable and can adapt to undesirable circumstances, it obscures the ways in which well-being can be assessed, and whether adaptation has improved or worsened the quality of life experienced. As Sen (1999:62) observes,

\section{failure to account for adaptive preferences when assessing individual well-being can be deeply unfair to those who are persistently deprived ... The deprived people tend to come to terms with their deprivation because of the sheer necessity of survival, and they may, as a result, lack the courage to demand any radical change, and may even adjust their desires and expectations to what they unambitiously see as feasible.}

It is people's capacity to put up with hardship that may foster resilience and, as such, they risk a reduction in well-being that needs to be considered. The adjustment of aspirations or resigned acceptance of misfortune (Sen 1990) also fits with the fatalistic view of life, which is frequently documented in fisheries society more generally (Marr 1981, Binkley 1995a, Murray et al. 1997, Pollnac et al. 1998).

This adaptation problem has been used in various ways to motivate the capability approach (see Sen 1985, Nussbaum and Sen 1993). Although there is insufficient scope here to detail Sen's capability approach in depth, there are some elements of the approach, and the centrality of agency within it, that are pertinent for a discussion on resilience and fisheries. In the approach, Sen uses two concepts: functionings and capabilities. Functionings are defined as the things a person may value doing or being. These valued functionings can range from meeting basic needs, such as eating sufficient food, to more complex functionings, such as participating in a community life and being respected (Sen 1999). Capabilities refer to different combinations of valued functions that are possible to achieve; what a person can actually do or be. Central to this idea are the choices open to people, and freedoms that people have or are denied, to live life in a way that they have reason to value (Sen 1999).

To illustrate this, Sen often gives the example of a fasting monk and a starving child: both may have the same functioning, in that they are both malnourished, but the monk can eat if he chooses to do so, and thus has a different capability set to a starving child who does not have the possibility to choose to eat and be well-nourished. Drawing from debates around adaptive preferences and social conditioning, Deneulin and Stewart (unpublished manuscript) argue that Sen's capabilities approach doesn't go far enough to consider agency within the context of social structures (see also Deneulin 2008). Using the same example of the monk and the fasting child, they question the degree of choice that the monk actually possesses, and the degree to which his choices are influenced by social structures and norms in which he lives; for example, aspects of social conditioning, the rules of the religious order, or his family background may all have shaped his choice to fast. The authors argue that Sen's framework is insufficient in its ability to evaluate a person's actual freedom to exercise their capabilities, stressing that capabilities can be socially conditioned, but equally socially deformed, which affects what and how decisions are made.

These debates are relevant for adaptation in fisheries and invite us to consider the freedoms and choices that people have in negotiating their own adaptation strategies toward fostering resilience. These can be conceptualized as different capability sets from which people have to choose, such as the option to leave a fishery and access an alternative livelihood. However, it also considers how those capabilities are valued by different people and, following Deneulin and Stewart (unpublished manuscript), how those values are shaped by social structures and norms. For example, an alternative livelihood to fishing is often advocated as an important adaptation strategy to cope with declining fishing income, and as a means to reduce fishing pressure and improve the resilience of the fishery system (Salayo et al. 2008, Cinner et al. 2009). However, if that alternative livelihood is not a valued way of life for the fisher, and if exiting the fishery would mean 'letting down' his crew members and other dependents in the fish chain, e.g., those who buy his fish, or involve a loss of prestige or social position, he may be unlikely to choose to adapt in this way.

\section{NEGOTIATING ADAPTATION CHOICES: AN ILLUSTRATIVE EXAMPLE}

This section connects the preceding debates with an illustrative example of a fisherman and a hypothetical decision making process around adaptation, which is then supported by evidence on actual adaptive strategies from the literature. The 
aim here is to provoke thought around how decisions are made in the context of complex social and cultural structures. The scenario used is that of a fisherman who continues to fish with diminishing returns/income, a scenario that is common to many fishers throughout the world as availability and access to fish decline. The fisherman faces some tough decision making and three plausible adaptation strategies are discussed: exit fisheries, livelihood diversification, or remain fishing. Each is considered in terms of his own agency, the influence of relations with others and broader social structures, and the trade-offs that emerge between resilience and well-being of the fisherman and his family.

\section{Exit strategy}

One adaptation strategy might be to employ personal and strategic agency to get out of fisheries completely and move into a more secure form of employment. A regular income, and removal of the risk of physical harm from a livelihood at sea (Pollnac et al. 1995, 1998), may serve to reduce the fisher's own vulnerability. Leaving fisheries may also increase the resilience of the household, through income stability, and the ecosystem, through reduced fishing pressure on the natural resource. However, the fisherman may also lose aspects of subjective well-being that are commonly valued among fishermen, particularly aspects of job satisfaction and selfactualization (Pollnac and Poggie 2008). As Pollnac and Poggie (2008:194) observe, "some fishermen resist leaving the occupation even when economic returns suggest they should." Fishers frequently describe fishing as being more than a livelihood, but an entire way of life, to which they are strongly attached (Binkley 1995b, Nadel-Klein 2003, van Ginkel 2007). As McGoodwin (1990) notes: "fishers tenaciously adhere to their occupation even as catches and incomes fall ... a persistence that often puzzles fisheries managers and economists who do not understand the noneconomic satisfactions derived from the occupation" (as cited in Pollnac et al. 2001:533).

\section{Diversification}

An alternative strategy might be to diversify his livelihood into parallel activities, to keep fishing, but diversify enough to get by, thereby exerting everyday and personal forms of agency. The livelihoods literature is full of evidence of fishers doing just that, particularly to cope during lean periods (McCay 2002, Béné et al. 2003, Pomeroy et al. 2006). As Allison and Ellis (2001) argue, fisherfolk diversify their livelihood for very good reasons such as the high risk of the occupation, seasonal fluctuation in the resource, and to reduce the risk of livelihood failure by spreading it across more than one income source. As Marschke and Berkes (2006) illustrate in the context of a small-scale fishery in Cambodia, fishers emphasized that the ability of household members to access multiple types of fishing gear and techniques, or to combine livelihood skills such as raising animals, contributed to the adaptability of the household and successful well-being. However, many fishers who diversify their livelihoods still keep one foot in their fishing boats. This is particularly evident in studies from Indonesia and the Philippines that describe the temporary diversification of fishers into seaweed farming, encouraged as a means of reducing fishing pressure (Sievanen et al. 2005). Many of the fishers involved moved back into fishing, sometimes purchasing new boats with the additional profits from seaweed sales. In many households the seaweed farms were tended by wives and children of fishers, with some women reporting a reduction in household chores and childcare as a result of their involvement (Crawford 2002). As is documented by Pollnac et al. (2001:531), through their work on job satisfaction among small-scale fishers in the Philippines, Indonesia, and Vietnam, "most fishers would not leave fishing for an alternative occupation, citing income as well as nonincome factors for resisting change."

\section{Remain fishing}

Taking into account this attachment to fishing as a valued way of life, a third, and more palatable, option for our fisherman might be to struggle through and keep fishing despite less income. Such a strategy may involve adapting his preferences for the present day, i.e., putting up with less, but perhaps keeping intact his future aspirations of a return to better catches and profit. Coulthard (2008) describes the tendency of fishermen in Pulicat Lagoon, India to sit and wait out lean seasons in the hope for a return to good catches. Although productivity usually returns to the lagoon, driven by good rains, lean seasons can last for months, and sometimes even years, during which time fishers and their families endure growing poverty. In such cases, the responsibility for resilience may pass to other family members such as wives and children who then risk becoming the buffers against an eroding fisheries livelihood. This was evident too in the previous example of seaweed farming; although Sievanen et al. (2005) acknowledge the contribution of a diversified household livelihood strategy in enabling adaptation to changing conditions, the trade-offs between household resilience and the well-being of individuals, and the agency people exert in accepting their part in creating resilience, is less clear. As the authors note, the impact of the introduction of seaweed farming on women and the overall household was not assessed.

Carr (2008) argues that the costs of adaptation strategies will not be distributed equally and, as a result, there will be winners and losers from any particular adaptation strategy (see also Osbahr et al. 2010). The literature on women in fisheries is particularly rich in its accounts of adaptation of women, their contributions to the resilience of the fishing household, and how this can result in costs to individual well-being. This tradeoff between adaptation and well-being is clearly evident in the following exert from Binkley's (1995b:87) study on Canadian fisher wives: 


\begin{abstract}
Since the economic wellbeing of the household depends on the husband's job, his wife's primary responsibility lies in supporting him. Her needs become secondary. Fishers work long hours, spend a good deal of time at sea, and work in one of the most dangerous occupations in Canada ... Husbands' absences from home further increase wives' independence and autonomy. They shoulder all the responsibility for the day to day running of the household as well as coping with emergencies that may arise. The nature of fishers' work sets up a dilemma for these women - how to balance the dependence / restriction set up by husband's work and the independence / autonomy needed to run the household. The balancing of these factors leads to the adaptation of fishermen's wives.
\end{abstract}

Here, Binkley refers to the "independence and autonomy" of women in running the household and coping with emergencies, but at the same time recognizes that "Her needs become secondary." This, again, draws our attention to the consequences of being adaptive, and in this case, increasing household resilience, on the well-being of the individual, and the agency that different people have in determining resilience.

While attending a conference organized by the North Sea Women's Network, the author had the opportunity to informally discuss fishing life with a group of trawler skipper's wives from Ireland and Scotland. The women were well aware of the hardships and uncertainties they faced; in light of declining catches and ever-stricter EU quota regimes, many women had taken on several jobs, often menial tasks such as cleaning, or working night shifts, to make financial ends meet in the home. The following was asked: "Don't you ever feel like putting your foot down and asking your husbands to get a proper job with a regular wage?" The response was unanimous: "We knew what this life would be when we married into it - it isn't just a job that you can replace with another, it is an entire way of life."

This response perhaps emphasizes the importance of agency in determining the degree of adaptation that women are willing to do; in accepting a proposal of marriage from a fisherman, knowing the life this will entail, they expand the breadth of what they are willing and able to compromise. Perhaps this is, in part, a reason behind historical in-marriage among fishers, as Nadel-Klein (2003:65) documents from early 20th Century fishing life in Scotland:

The usual explanation given for in-marriages among fishers from the same village was that " a fisher laddie needs a fisher lassie." Indeed, this was not merely a euphonious aphorism or romantic ideal. Fishermen consciously sought wives who would be effective helpmates. As one man said to me, "Ye had to marry wi' in the fisherfolk. Ye needed

a wife who knew the wark."

Here, again, the social and cultural context in which agency is exercised comes to the fore. If the woman getting married is already part of the fishing society, to what degree have cultural structures, and relationships with others, shaped her agency in deciding to marry a fisherman and all that the lifestyle involves? Nadel-Klein (2003:66) recognizes this and comments, "It can just as well be argued that a fisher lassie needs a fisher lassie," pointing out that the close organization around core groups of kin and strong bonds between women, mothers and daughters especially, made women reluctant to marry outside of their home village. She further argues that intermarriage in fishing communities can serve to reinforce solidarity in the face of social stigma relating to fishing communities (see van Ginkel 2007). Such solidarity has persisted throughout fisheries worldwide, as can be evidenced in the activities of Women in Fisheries networks and their tireless campaigning for fisher rights (see wif.icsf.net).

\section{CONCLUSION}

If adaptation is to be facilitated and negotiated at the local level (Smit and Wandel 2006), the question of what shapes adaptation decision making, and how this influences resilience of the broader social-ecological system, is critical and yet unresolved in the literature (Carr 2008, Bohle et al. 2009). A narrow interpretation of adaptation as a rational decision making process constrained largely by resources and technology, can obscure the value-laden and societal limits to adaptation and the ways in which different strategies are negotiated (Adger et al. 2007, 2008, Inderberg and Eikeland 2009). As has been illustrated in this paper, the duel goals of fostering resilience and decision making around well-being may pull in different directions and involve trade-offs and hard choices. Understanding these trade-offs and the decision making processes that underline them necessitates a deeper assessment of the range of consequences that are incurred through adaptation for different people (Carr 2008, Turner et al. 2008), but also acknowledgment of the problem of adaptive preferences in assessing these impacts. Policy agendas toward enhanced resilience in fisheries, and further afield, therefore need to engage more with the question of how resilience affects well-being, and the degree of agency people have in determining their responses to environmental change. As has been argued here, the concept of agency, in particular, has capacity to connect resilience thinking at a systems level, with actor-orientated negotiations at an individual level.

Elucidating the complexities of adaptation negotiations with greater transparency of well-being outcomes affected is ultimately a challenge for governance (Coulthard et al. 2011). Within resilience debates, adaptive governance has come a long way in connecting different actors across multiple levels, with a focus on capacity to reorganize the system in response 
to change or a disturbance (Tompkins and Adger 2004, Folke et al. 2005). However, we also need platforms for deliberation of trade-offs (Steins and Edwards 1999) from an actororientated perspective. Making these hard choices more visible in governance processes (Bailey and Jentoft 1990, Kooiman et al. 2005) is a step toward empowering people to determine their own balance between being well or being resilient, or the ambitious pursuit of both.

Responses to this article can be read online at:

http://www.ecologyandsociety.org/voll7/iss1/art4/responses/

\section{Acknowledgments:}

Early versions of this paper were presented at the World SmallScale Fisheries Congress, Bangkok, Thailand, Oct 18-22, 2010; and at the "Governing Small-scale Fisheries for Wellbeing and Resilience: A Canada-WorldFish Centre Collaborative Project", Workshop June 2010, WorldFish Headquarters, Penang. The author is grateful for comments received at both events, and also from two anonymous reviewers.

\section{LITERATURE CITED}

Abercrombie, N. M., S. M. Hill, and B. S. Turner. 1984. Dictionary of sociology. Penguin, New York, New York, USA.

Adger, W. N. 2000. Social and ecological resilience: are they related? Progress in Human Geography 24:347-364. http://dx .doi.org/10.1191/030913200701540465

Adger, W. N. 2003. Social capital, collective action and adaptation to climate change. Economic Geography 79:387-404. http://dx.doi.org/10.1111/j.1944-8287.2003.tb00220. $\underline{\mathrm{X}}$

Adger, W. N. 2006. Vulnerability. Global Environmental Change 16:268-281. http://dx.doi.org/10.1016/j.gloenvcha.20 $\underline{06.02 .006}$

Adger, W. N. 2010. Climate change, human well-being and insecurity. New Political Economy 15(2):275-292. http://dx.d oi.org/10.1080/13563460903290912

Adger, W. N., S. Agrawala, M. M. Q. Mirza, C. Conde, K. O'Brien, J. Pulhin, R. Pulwarty, B. Smit, and K. Takahashi. 2007. Assessment of adaptation practices, options, constraints and capacity. Pages 717-743 in M. L. Parry, O. F. Canziani, J. P. Palutikof, P. J. van der Linden, and C. E. Hanson, editors. Climate change 2007: impacts, adaptation and vulnerability. Contribution of Working Group II to the Fourth Assessment Report of the Intergovernmental Panel on Climate Change. Cambridge University Press, Cambridge, UK.
Adger, W. N., S. Dessai, M. Goulden, M. Hulme, I. Lorenzoni, D. R. Nelson, L. O. Naess, J. Wolf, and A. Wreford. 2008. Are there social limits to adaptation to climate change? Climatic Change 93(3-4):335-354. http://dx.doi.org/10.1007/ $\underline{\mathrm{s} 10584-008-9520-\mathrm{z}}$

Adger, W. N., T. P. Hughes, C. Folke, S. R. Carpenter, and J. Rockström. 2005. Social-ecological resilience to coastal disasters. Science 309(5737):1036-1039. http://dx.doi.org/10 $\underline{.1126 / \text { science. } 1112122}$

Allison, E. H., N. L. Andrew, and J. Oliver. 2007. Enhancing the resilience of inland fisheries and aquaculture systems to climate change. Journal of Semi-Arid Tropical Agricultural Research 4(1):35.

Allison, E. H., and F. Ellis. 2001. The livelihoods approach and management of small-scale fisheries. Marine Policy 25 (5):377-388. http://dx.doi.org/10.1016/S0308-597X(01)00023-9

Allison, E. H., and B. Horemans. 2006. Putting the principles of the sustainable livelihoods approach into fisheries development policy and practice. Marine Policy 30 (6):757-766. http://dx.doi.org/10.1016/j.marpol.2006.02.001

Allison, E. H., A. L. Perry, M. C. Badjeck, W. N. Adger, K. Brown, D. Conway, A. S. Halls, G. M. Pilling, J. D. Reynolds, N. L. Andrew, and N. K. Dulvy. 2009. Vulnerability of national economies to the impacts of climate change on fisheries. Fish and Fisheries 10(2):173-196. http://dx.doi.org /10.1111/j.1467-2979.2008.00310.x

Armitage, D., M. Marschke, and R. Plummer. 2008. Adaptive co-management and the paradox of learning. Global Environmental Change 18(1):86-98. http://dx.doi.org/10.1016/ j.gloenvcha.2007.07.002

Armitage, D., and R. Plummer, editors. 2010. Adaptive capacity and environmental governance. Springer Series on Environmental Management, Springer, New York, New York, USA. http://dx.doi.org/10.1007/978-3-642-12194-4

Bailey, C., and S. Jentoft. 1990. Hard choices in fisheries development. Marine Policy 14(4):333-344. http://dx.doi.org /10.1016/0308-597X(90)90055-V

Bavinck, J. M. 2001. Marine resource management. Conflict and regulation in the fisheries of the Coromandel Coast. Sage, New Delhi, India.

Bavinck, J. M. 2005. Understanding Fisheries Conflicts in the South-A Legal Pluralist Perspective. Society \& Natural Resources 18 (9):805-820. http://dx.doi.org/10.1080/0894192 $\underline{0500205491}$

Bavinck, J. M., and E. Hoefnagel. 2005. Capitulate, dodge, protest... State intervention in the fisheries of the Netherlands 
has forced fishers to adopt interesting coping strategies. Samudra 32(41):17-23.

Beddington, J. R., D. J. Agnew, and C. W. Clark. 2007. Current problems in the management of marine fisheries. Science 316:1713-1716. http://dx.doi.org/10.1126/science.1137362

Béné, C. 2009. Are fishers poor or vulnerable? Assessing economic vulnerability in small-scale fishing communities. Journal of Development Studies 45(6):911-933. http://dx.doi. org/10.1080/00220380902807395

Béné, C., A. Neiland, T. Jolley, S. Ovie, O. Sule, B. Ladu, K. Mindjimba, E. Belal, F. Tiotsop, M. Baba, L. Dara, A. Zakara, and J. Quensiere. 2003. Inland fisheries, poverty, and rural livelihoods in the Lake Chad Basin. Journal of Asian and African Studies 38(1):17-51. http://dx.doi.org/10.1177/00219 $\underline{0960303800102}$

Bennett, E. 2005. Gender, fisheries and development. Marine Policy 29:451-459. http://dx.doi.org/10.1016/j.marpol.2004.07.003

Berkes, F., and C. Folke, editors. 1998. Linking social and ecological systems: management practices and social mechanisms for building resilience. Cambridge University Press, Cambridge, UK.

Berkes, F., and D. Jolly. 2001. Adapting to climate change: social-ecological resilience in a Canadian western Arctic community. Conservation Ecology 5(2):18.

Binkley, M. 1995b. Lost moorings: offshore fishing families coping with the fisheries crisis after the collapse. Dalhousie Law Journal 18(1):82-95.

Binkley, M. 1995a. Risks, dangers and rewards in the Nova Scotia offshore fishery. McGill-Queen's University Press, Montreal, Quebec, Canada.

Binkley, M. 2000. Getting by in tough times: coping with the fisheries crisis. Women's Studies International Forum 23:323-332. http://dx.doi.org/10.1016/S0277-5395(00)00090$\underline{X}$

Bodin, Ö., and B. I. Crona. 2009. The role of social networks in natural resource governance: what relational patterns make a difference? Global Environmental Change 19:366-374. htt p://dx.doi.org/10.1016/j.gloenvcha.2009.05.002

Bohle, H.-G., B. Etzold, and M. Keck. 2009. Resilience as agency. International Human Dimension Programme Update 2:8-13. [online] URL: http://www.ihdp.unu.edu/article/read/r esilience-as-agency

Bourdieu, P. 1990. The logic of practice. Polity, Cambridge, UK.

Brooks, N., W. N. Adger, and P. M. Kelly. 2005. The determinants of vulnerability and adaptive capacity at the national level and the implications for adaptation. Global Environmental Change 15:151-163. http://dx.doi.org/10.1016/ j.gloenvcha.2004.12.006

Camfield, L., and A. McGregor. 2005. Resilience and wellbeing in developing countries. Pages 189-209 in M. Ungar, editor. Handbook for working with children and youth: pathways to resilience across cultures and contexts. Sage, Thousand Oaks, California, USA.

Carr, E. R. 2008. Between structure and agency: livelihoods and adaptation in Ghana's central region. Global Environmental Change 18:689-699. http://dx.doi.org/10.1016/ j.gloenvcha.2008.06.004

Cinner, J., T. Daw, and T. R. McClanahan. 2009. Socioeconomic factors that affect artisanal fishers' readiness to exit a declining fishery. Conservation Biology 23 (1):124-130. http://dx.doi.org/10.1111/j.1523-1739.2008.01041. $\underline{\mathrm{x}}$

Clark, D. A. 2007. Adaptation, poverty and well-being: some issues and observations with special reference to the capability approach and development studies. Working Paper GPRGWPS-081 Global Poverty Research Group, University of Manchester, UK.

Coulthard, S. 2008. Adapting to environmental change in artisanal fisheries - insights from a South Indian lagoon. Global Environmental Change 18(3):479-489. http://dx.doi.o rg/10.1016/j.gloenvcha.2008.04.003

Coulthard, S. 2009. Adaptation and conflict within fisheries: insights for living with climate change. Pages 255-268 in W. N. Adger, I. Lorenzoni, and K. L. O'Brien, editors. 2009. Adapting to climate change: thresholds, values and governance. Cambridge University Press, Cambridge, UK. http://dx.doi.org/10.1017/CBO9780511596667.017

Coulthard, S., D. Johnson, and J. A. McGregor. 2011. Poverty, sustainability and human wellbeing: a social wellbeing approach to the global fisheries crisis. Global Environmental Change 21:453-463. http://dx.doi.org/10.1016/j.gloenvcha.20 11.01 .003

Crawford, B. 2002. Seaweed farming: an alternative livelihood for small-scale fishers? Working paper for the Coastal Resources Centre, University of Rhode Island, Kingston, Rhode Island, USA. [online] URL: http://www.crc. uri.edu/download/Alt_Livelihood.pdf

Crona, B., and K. Hubacek. 2010. The right connections: how do social networks lubricate the machinery of natural resource governance? Ecology and Society 15(4): 18. [online] URL: http://www.ecologyandsociety.org/vol15/iss4/art18

Davies, S. 1996. Adaptable livelihoods: coping with food insecurity in the Malian Sahel. Macmillan, London, UK. 
Daw, T., W. N. Adger, K. Brown, and M. C. Badjeck. 2009. Climate change and capture fisheries: potential impacts, adaptation and mitigation. Pages 107-150 in K. Cochrane, C. De Young, D. Soto, and T. Bahri, editors. Climate change implications forfisheries and aquaculture: overview of current scientific knowledge. FAO Fisheries and Aquaculture Technical Paper No. 530. FAO, Rome, Italy.

Deneulin, S. 2008. Beyond individual freedom and agency: structures of living together in Sen's capability approach to development. Pages 105-124 in S. Alkire, F. Comim, and M. Qizilbash, editors. The capability approach: concepts, measures and application. Cambridge University Press, Cambridge, UK.

Dietz, T., E. Ostrom, and P. C. Stern. 2003. The struggle to govern the commons. Science 302:1902-1912. http://dx.doi.o rg/10.1126/science.1091015

Ellis, F. 2000. Rural livelihoods and diversity in developing countries. Oxford University Press, Oxford, UK.

Finlayson, C. A., and B. J. McCay. 1998. Crossing the threshold of ecosystem resilience: the commercial extinction of the northern cod. Chapter 12 in F. Berkes and C. Folke, editors. 1998. Linking social and ecological systems: management practices and social mechanisms for building resilience. Cambridge University Press, Cambridge, UK.

Folke, C. 2006. Resilience: the emergence of a perspective for social-ecological systems analyses. Global Environmental Change 16(3):253-267. http://dx.doi.org/10.1016/j.gloenvcha .2006 .04 .002

Folke, C., S. R. Carpenter, B. Walker, M. Scheffer, T. Chapin, and J. Rockström. 2010. Resilience thinking: integrating resilience, adaptability and transformability. Ecology and Society 15(4): 20. [online] URL: http://www.ecologyandsociety. org/vol15/iss4/art20/

Folke, C., T. Hahn, P. Olsson, and J. Norberg. 2005. Adaptive governance of social-ecological systems. Annual Review of Environment and Resources 30:441-473. http://dx.doi.org/10 .1146/annurev.energy.30.050504.144511

Food and Agricultural Organization (FAO). 2007. Building adaptive capacity to climate change. Policies to sustain livelihoods and fisheries. New directions in fisheries. A series of policy briefs on development issues. No. 08. FAO, Rome, Italy.

Gallopín, G. C. 2006. Linkages between vulnerability, resilience, and adaptive capacity. Global Environmental Change 16(3):293-303. http://dx.doi.org/10.1016/j.gloenvcha .2006 .02 .004

Garcia, S. M., and A. T. Charles. 2008. Fishery systems and linkages: implications for science and governance. Ocean \&
Coastal Management 51(7):505-527. http://dx.doi.org/10.1016/ j.ocecoaman.2008.05.001

Giddens, A. 1976. New rules of sociological method. Hutchinson, London, UK.

Giddens, A. 1984. The constitution of society: outline of the theory of structuration. Polity, Cambridge, UK.

Gough, I., and J. A. McGregor, editors. 2007. Wellbeing in developing countries: from theory to research. Cambridge University Press, Cambridge, UK.

Gunderson, L., and C. S. Holling, editors. 2002. Panarchy: understanding transformations in human and natural systems. Island Press, Washington, D.C., USA.

Hauck, M. and M. Kroesse. 2006. Fisheries compliance in South Africa: A decade of challenges and reform 1994-2004. Marine Policy 30(1):74-83. http://dx.doi.org/10.1016/j.marpo $\underline{1.2005 .06 .007}$

Inderberg, T. H., and P. O. Eikeland. 2009. Limits to adaptation: analysing institutional constraints. Pages 433-447 in W. N. Adger, I. Lorenzoni, and K. O'Brien, editors. 2009. Adapting to climate change: thresholds, values, governance. Cambridge University Press, Cambridge, UK. http://dx.doi.o rg/10.1017/CBO9780511596667.028

Jackson, J. B. C., M. X. Kirby, W. H Berger, K. A. Bjorndal, L. W. Botsford, B. J. Bourque, R. H. Bradbury, R. Cooke, J. Erlandson, J. A. Estes, T. P. Hughes, S. Kidwell, C. B. Lange, H. S. Lenihan, J. M. Pandolfi, C. H. Peterson, R. S. Steneck, M. J. Tegner, and R. R. Warner. 2001. Historical overfishing and the recent collapse of coastal ecosystems. Science 293 (5530):629-637. http://dx.doi.org/10.1126/science.1059199

Jentoft, S. 2004. Institutions in fisheries: what they are, what they do, and how they change. Marine Policy 28(2):137-149. http://dx.doi.org/10.1016/S0308-597X(03)00085-X

Jentoft, S., and B. J. McCay. 2003. The place of civil society in fisheries management: a research agenda for fisheries comanagement. Chapter 17 in D. C. Wilson, J. R. Nielsen, and P. Degnbol, editors. The fisheries co-management experience; accomplishments, challenges and prospects. Fish and Fisheries Series 26, Kluwer Academic, Dordrecht, The Netherlands.

Kooiman, J., M. Bavinck, S. Jentoft, and R. Pullin, editors. 2005. Fish for life: interactive governance for fisheries. MARE Publication Series 3, Amsterdam University Press, Amsterdam, The Netherlands. http://dx.doi.org/10.5117/9789 $\underline{053566862}$

Lister, R. 2003. Citizenship: feminist perspectives. Second Edition. New York University Press, New York, New York, USA. 
Lister, R. 2004. Poverty. Polity, Cambridge, UK.

Long, N., and A. Long. 1992. Battlefields of knowledge: the interlocking of theory and practice in social research and development. Routledge, London, UK.

Long, N., and J. D. van der Ploeg. 1994. Heterogeneity, actor and structure: towards a reconstitution of the concept of structure. In D. Booth, editor. Rethinking social development: theory, research and practice. Longman Scientific and Technical, Essex, UK.

Marchal, P., J. J. Poos, and F. Quirijns. 2007. Linkage between fishers' foraging, market and fish stocks density: examples from some North Sea fisheries. Fisheries Research 83 (1):33-43. http://dx.doi.org/10.1016/j.fishres.2006.08.025

Marr, J. C. 1981. The realities of fishery management in the Southeast Asia region. Pages 299-307 in D. Pauly and G.I. Murphy, editors. Theory and management of tropical fisheries. Proceedings of the ICLARM / CSIRO workshop on the theory and management of tropical multi-species stocks, 12-21 January 1981, Cronulla, Australia. International Center for Living Aquatic Resources Management, Manila, Philipines, and Division of Fisheries Research, Commonwealth Scientific and Industrial Research Organisation, Cronulla, Australia.

Marschke, M. J., and F. Berkes. 2006. Exploring strategies that build livelihood resilience: a case from Cambodia. Ecology and Society 11(1): 42. [online] URL: http://www.eco logyandsociety.org/vol11/iss1/art42/

McCay, B. J. 2002. Emergence of institutions for the commons: contexts, situations, and events. Pages 361-402 in E. Ostrom, T. Dietz, N. Dolsak, P. C. Stern, S. Stonich, and E. U. Weber, editors. The drama of the commons. National Academy Press, Washington D.C., USA.

McLaughlin, P., and T. Dietz. 2008. Structure, agency and environment: toward an integrated perspective on vulnerability. Global Environmental Change 18(1):99-111. http://dx.doi.org/10.1016/j.gloenvcha.2007.05.003

McGregor, J. A. 2009. Human wellbeing in fishing communities. Paper prepared for ESPA Workshop 1, April 2009, Institute for Ocean Management, Chennai, India. [online] URL: http://www.wellcoast.org/wp-content/uploads/ docs/Wellbeingandfisheries.pdf

Millennium Ecosystem Assessment (MEA). $2005 a$. Ecosystems and human well-being: general synthesis. Island Press, Washington, D.C., USA.

Millennium Ecosystem Assessment (MEA). $2005 b$. Ecosystems and human well-being: health synthesis. Island Press, Washington, D.C., USA.

Millennium Ecosystem Assessment (MEA). $2005 c$. Ecosystems and human well-being: current state and trends. Island Press, Washington, D.C., USA.
Murray, M., D. Fitzpatrick, and C. O'Connell. 1997. Fishermens blues: factors related to accidents and safety among Newfoundland fishermen. Work \& Stress 11 (3):292-297. http://dx.doi.org/10.1080/02678379708256842

Nadel Klein, J. 2003. Fishing for heritage: modernity and loss along the Scottish coast. Berg, Oxford, UK.

Nelson, D. R, W. N. Adger, and K. Brown. 2007. Adaptation to environmental change: contributions of a resilience framework. Annual Review of Environment and Resources 32:395-419. http://dx.doi.org/10.1146/annurev.energy.32.051 807.090348

Nussbaum, M. C. 2001. Adaptive preferences and women's options. Economics and Philosophy 17:67-88. http://dx.doi.o rg/10.1017/S0266267101000153

Nussbaum, M., and A. Sen, editors. 1993. Quality of life. Clarenden Press, Oxford, UK. http://dx.doi.org/10.1093/0198 $\underline{287976.001 .0001}$

O'Brien, K. 2009. Do values subjectively define the limits to climate change adaptation? Pages 255-268 in W. N. Adger, I. Lorenzoni, and K. L. O'Brien, editors. Adapting to climate change: thresholds, values and governance. Cambridge University Press, Cambridge, UK.

Osbahr, H., C. Twyman, W. N. Adger, and D. S. G. Thomas. 2010. Evaluating successful livelihood adaptation to climate variability and change in southern Africa. Ecology and Society 15(2): 27. [online] URL: http://www.ecologyandsociety.org/v ol15/iss2/art27/

Ostrom, E., J. Burger, C. B. Field, R. B. Norgaard, and D. Policansky. 1999. Revisiting the commons: local lessons, global challenges. Science 284:278-282. http://dx.doi.org/10. $\underline{1126 / \text { science. } 284.5412 .278}$

Paavola, J., and W. N. Adger. 2005. Fair adaptation to climate change. Ecological Economics 56:594-609. http://dx.doi.org/ 10.1016/j.ecolecon.2005.03.015

Panter-Brick, C. 2002. Street children, human rights and public health: a critique and future directions. Annual Review of Anthropology 31:147-171. http://dx.doi.org/10.1146/annurev. anthro.31.040402.085359

Pauly, D., V. Christensen, S. Guénette, T. J. Pitcher, U. R. Sumaila, C. J. Walters, R. Watson, and D. Zeller. 2002. Towards sustainability in world fisheries. Nature 418:689-695. http://dx.doi.org/10.1038/nature01017

Pollnac, R. B., and J. J. Poggie. 2008. Happiness, well-being and psychocultural adaptation to the stresses associated with marine fishing. Human Ecology Review 15(2):194-200.

Pollnac, R. B., J. J. Poggie, and C.van Dusen. 1995. Cultural adaptation to danger and the safety of commercial oceanic fishermen. Human Organization 54(2):153-159. 
Pollnac, R. B., J. J. Poggie, and S. L. Cabral. 1998. Thresholds of danger: perceived risk in a New England fishery. Human Organization 57(1):53-59.

Pollnac, R. B., R. Pomeroy, and I. H. T. Harkes. 2001. Fishery policy and job satisfaction in three southeast Asian fisheries. Ocean and Coastal Management 44:531-544. http://dx.doi.or $\mathrm{g} / 10.1016 / \mathrm{S} 0964-5691(01) 00064-3$

Pomeroy, R. S, B. D. Ratnera, S. J. Hall, J. Pimoljinda, and V. Vivekanandan. 2006. Coping with disaster: rehabilitating coastal livelihoods and communities. Marine Policy 30 (6):786-793. http://dx.doi.org/10.1016/j.marpol.2006.02.003

Qizilbash, M. 2006. Well-being, adaptation and human limitations. Royal Institute of Philosophy Supplement 59:83-110. http://dx.doi.org/10.1017/S1358246106059054

Ram, K. 1991. Mukkuvar women: gender, hegemony and capitalist transformation in a South Indian fishing community. Women in Asia Series, Asian Studies Association of Australia, Zed Press and Kali Press for Women, New Delhi, India.

Salayo, N., L. Garces, M. Pido, K. Viswanathan, R. Pomeroy, M. Ahmed, I. Siason, K. Seng, and A. Masae. 2008. Managing excess capacity in small-scale fisheries: perspectives from stakeholders in three Southeast Asian countries. Marine Policy 32(4):692-700. http://dx.doi.org/10.1016/j.marpol.2007.12.001

Sen, A. K. 1985. Commodities and capabilities. Elsevier, Amsterdam, The Netherlands.

Sen, A. K. 1990. Gender and co-operative conflicts. Pages 123-149 in I. Tinker, editor. Persistent inequalities. Oxford University Press, Oxford, UK.

Sen, A. K. 1999. Development as freedom. Oxford University Press, Oxford, UK.

Sievanen, L., B. Crawford, R. Pollnac, and C. Lowe. 2005. Weeding through assumptions of livelihood approaches in ICM: Seaweed farming in the Philippines and Indonesia. Ocean Coastal Management 48:297-313. http://dx.doi.org/10 .1016/j.ocecoaman.2005.04.015

Smit, B., and J. Wandel. 2006. Adaptation, adaptive capacity and vulnerability. Global Environmental Change 16 (3):282-292. http://dx.doi.org/10.1016/j.gloenvcha.2006.03.008

Steins, N. A., and V. M. Edwards. 1999. Platforms for collective action in multiple-use common-pool resources. Agriculture and Human Values 16:241-255. http://dx.doi.org/ 10.1023/A:1007591401621

Sunde, J. 2008. Building resilience or transformation? Samudra 51:20-25.
Sunde, J., and M. Isaacs. 2008. Marine conservation and coastal communities: who carries the costs? A study of marine protected areas and their impact on traditional small-scale fishing communities in South Africa. Samudra Monograph. International Collective in Support of Fishworkers, Chennai, India. [online] URL: http://icsf.net/icsf2006/uploads/publications/ monograph/pdf/english/issue_93/ALL.pdf

Tompkins, E. L., and W. N. Adger. 2004. Does adaptive management of natural resources enhance resilience to climate change? Ecology and Society 9(2): 10. [online] URL: http://w ww.ecologyandsociety.org/vol9/iss2/art10/

Turner, N. J., R. Gregory, C. Brooks, L. Failing, and T. Satterfield. 2008. From invisibility to transparency: identifying the implications. Ecology and Society 13(2): 7. [online] URL: http://www.ecologyandsociety.org/vol13/iss2/ $\underline{\operatorname{art} 71}$

van Ginkel, R. 2007. Coastal cultures: an anthropology of fishing and whaling traditions. Spinhuis, Apeldoorn, The Netherlands.

Walker, B., C. S. Holling, S. R. Carpenter, and A. Kinzig. 2004. Resilience, adaptability and transformability in socialecological systems. Ecology and Society 9(2): 5. [online] URL: http://www.ecologyandsociety.org/vol9/iss2/art5/

World Bank/FAO/WorldFish Center. 2010. The hidden harvests: the global contribution of capture fisheries. Agriculture and Rural Development Department, Sustainable Development Network. World Bank, Washington D.C., USA.

WorldFish Center. 2010. Policies and practice for resilience. WorldFish Center, Bayan Lepas, Penang, Malaysia. [online] URL: http://www.worldfishcenter.org/our-research/researchfocal-areas/policies-and-pr actice-resilience- 0

Worm, B., R. Hilborn, J. K. Baum, T. A. Branch, J. S. Collie, C. Costello, M. J. Fogarty, E. A. Fulton, J. A. Hutchings, S. Jennings, O. P. Jensen, H. K. Lotze, P. M. Mace, T. R. McClanahan, C. Minto, S. R. Palumbi, A. M. Parma, D. Ricard, A. A. Rosenberg, R. Watson, and D. Zeller. 2009. Rebuilding global fisheries. Science 325(5940):578-585.

Young, O. R., F. Berkhout, G. C. Gallopin, M. Janssen, E. Ostrom, and S. van der Leeuw. 2006. The globalization of socio-ecological systems: an agenda for scientific research. Global Environmental Change 16:304-316. http://dx.doi.org/ 10.1016/j.gloenvcha.2006.03.004 